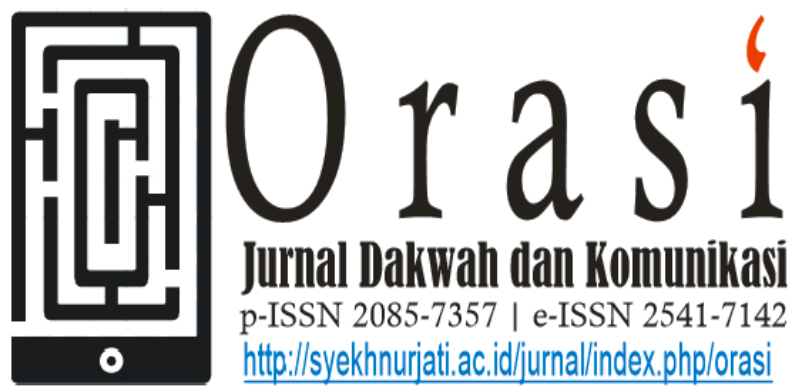

Volume 9 No. 2, PP 29 - 42; November 2018

\title{
DAKWAH MELALUI FILM ANIMASI
}

\author{
Arief Rachman1(*), Ismi Nadiyati2 \\ Dosen Jurusan Komunikasi dan Penyiaran Islam ${ }^{1}$ \\ Mahasiswa Jurusan Komunikasi dan Penyiaran Islam ${ }^{2}$ \\ Fakultas Ushuluddin Adab dan Dakwah IAIN Syekh Nurjati Cirebon
}

rachmancirebon@yahoo.com $^{(*)}, \underline{\text { Isminadiyati10@gmail.com }}$

\begin{abstract}
ABSTRAK
Sabar membutuhkan proses, mental yang kuat, utuk menghadapi bebagai macam masalah, musibah, bersabar dalam beribadah, dan bersabar dalam sekolah dapat nilai jelek, menahan lapar. Pertanyaan dalam penelitian ini adalah: (1) Bagaimana pesan dakwah yang terkandung dalam film animasi Syamil dan Dodo dengan judul "Sabar"? (2) Bagaimana strategi penyampaian pesan dalam film animasi Syamil dan Dodo? Tujuan dari penelitian ini untuk mengetahui pesan-pesan dakwah yang tekandung dalam film animasi Syamil dan Dodo dengan judul Sabar. Untuk mengetahui strategi penyampaian dalam film animasi Syamil dan Dodo. Dan penelitian pesan pada film Syamil dan Dodo ini, diharapkan untuk dapat memberikan referensi untuk anak-anak dalam pendidikan agama. Penelitian ini menggunakan pendekatan Kualitatif dengan metode analisis Roland Barthes, yang menganalisis peradegan-adegan pada film animasi Syamil dan Dodo yang bejudul Sabar. Dari paparan di atas dapat disimpulkan pesan dakwah pada film animasi Syamil dan Dodo ini, Pesan dakwah dalam penelitian Film Syamil dan Dodo yaitu mengajarkan kesabaran dengan cara kemasan anak-anak, supaya anakanak mengerti dan tidak keliru memahami arti sabar. Televisi dapat membentuk suatu karakter seseorang apalagi anak kecil yang mudah meniru apa yang mereka lihat dan apa yang mereka denga. Televisi mempunyai dua hal sisi baik dan juga sisi buruknya. Sisi baiknya adalah di dalam televisi ketika program baik, maka ia dapat memberikan pesan-pesan yang sangat baik.
\end{abstract}

Kata kunci: Sabar, televisi, karakter, program, anak 


\section{PENDAHULUAN}

Komunikasi massa adalah pesan yang dikomunikasikan melalui media massa pada sejumlah besar orang (Ardianto, 2012:3). Media massa terdiri dari beberapa bentuk yaitu surat kabar, majalah, radio, televisi, dan film. Diantara semua media massa, televisi yang paling berpengaruh pada kehidupan manusia. Tayangan televisi diisi oleh hiburan, berita, dan iklan (Ardianto, 2012:134).

Diantara tayangan-tayangan di televi yang paling banyak peminatnya adalah program hiburan.Seperti yang dikatakan Dominick, kekuatan yang dominan pada televisi adalah sebagai medium hiburan. ${ }^{1}$ Banyak sekali program hiburan yang menghiasi layar kaca seperti film animasi.

Film animasi anak-anak saat ini tidak hanya menawarkan hiburan, tapi juga memberikan pesan-pesan yang mengajak ke jalan yang benar atau dakwah. Seperti yang dikatakan Aziz, Dakwah adalah mengajak atau menyeru untuk melakukan kebajikan dan mencegah kemungkaran, mengubah umat dari satu situasi kepada situasi lain yang lebih baik dalam segala bidang, merealisasi ajaran islam dalam kehidupan sehari-hari bagi seorang pribadi, keluarga,

1 Aretha Kurnia. 2009. Persepsi Ibu Rumah Tangga Kelurahan Tomang pada Tayangan Sinetron Inayah di Indosiar.http://digilib.mercubuana.ac.id/manager/n!@fil e_skripsi/44105010053\%20Aretha\%20Kurnia.pdf. (diunduh pada tanggal 18 desember 2017, pukul 15.33 WIB) kelompok atau massa, serta bagi kehidupan masyarakat sebagai keseluruhan tata hidup bersama dalam rangka pembangunan bangsa dan umat manusia (Aziz, 2014:13).

Televisi sebagai media dakwah, yang berfungsi sebagai media yang mengayomi arus tren tahun dua ribuan sebagai media hiburan, media informasi, media politik, dan media pendidika.Dengan pergeseran budaya masyarakat yang terus berubah, fungsi televisi digunakan sebagai media dakwah bagi berbagai agama, baik secara terpisah, seperti melalui program khusus siraman keagamaan maupun secara inhern muatanmuatan nilai yang terkandung dalam program acara televisi. Meskipun fungsi dakwah dalam televisi masih sangat minim, tidak menutupi kemungkinan, apabila televisi dengan segala unsurnya mulai melempar acara-acara dengan kemasan nilainilai agama islam, maka islam "dalam tataran sosiologis" akan makin menggema melalui dakwah di media televisi (Aripudin, 2013: 34-35).

Peran media dakwah menurut Mira Fauziyah, dapat diartikan sebagai alat atau sarana yang digunakan untuk berdakwah dengan tujuan supaya memudahkan penyampaian pesan dakwah kepada mad'u. Alat bantu media dakwah merupakan unsur tambahan dalam kegiatan dakwah. Artinya kegiatan dakwah dapat berlangsung, meski tanpa media. Maka hal tersebut jika berpegangan bahwa media selalu merupakan 
alat atau sarana untuk menyampaikan pesan dakwah kepada mitra dakwah (Aziz, 2014:403-404 ).

Maka dari itu, begitu pentingnya pengaruh televisi untuk membentuk suatu karakter seseorang apalagi anak kecil yang mudah meniru apa yang mereka lihat dan apa yang mereka dengar, itu sangat berpotensi sekali membentuk karakter seseorang dari mulai kecil. Oleh karena itu televisi mempunyai dua hal sisi baik dan juga sisi buruknya. Sisi baiknya adalah di dalam televisi ketika program baik, maka ia dapat memberikan pesan-pesan yang sangat baik.Ada beberapa televisi menyiarkan animasi yang mana biasanya sangat disukai anak-anak, salah satu program yang paling mempunyai edukasi adalah film animasi Syamil dan Dodo.

Film animasi Syamil dan Dodo masuk nominasi anugerah Komisi Penyiaran Indonesia ( $\underline{\text { KPI }}$ ) Pusat. Tayangan di RTV soal agama ini menceritakan Syamil yang baik hati dan Dodo yang nakal.Kisahnya lucu dengan kepolosan anak-anak ${ }^{2}$.

Film Syamil dan Dodo iniedisi tentang sabar, arti sabar itu adalah kemampuan menahan diri yang terbagi dalam dua macam, yang pertama kesabaran yang

2https://www.merdeka.com/peristiwa/film-kartunsyamil-dan-dodo-masuk-nominasi-kpi-award-

2014.html. (diundu pada tanggal 22 desember 2017, pukul 14.30 WIB) berkaitan dengan fisik seperti ketabahan memikul beban, kesabaran beribadah seperti sholat dan puasa, dan juga sabar itu dalam hal ketabahan menahan luka parah atau lukaluka yang sangat menyakitkan, yang kedua kesabaran yang berkaitan dengan jiwa, misalnya menahan diri dari berbagai ta'biat dan nafsu yang jelek, misalnya menahan diri untuk tidak marah-marah, tidak berbuat jahat pada orang lain, tidak berbohong dan sebagainya. Dan di video ini mengajarkan tentang arti sebuah tanggung jawab, tidak boleh berbicara kasar kepada orang tua, dan kesabara itu tidak boleh pilih-pilih tempat disemua keadan harus bersabar. ${ }^{3}$

Salah satu program yang menggambarkan proses seputar keagamaan dalam film animasi Syamil dan Dodo serial televisi animasi anak-anak yang dirillis pada 8 juni2013 di Indonesia dan disiarkan di TV Swasta. Serial ini diproduksi oleh PT RumahAnimasi Indonesia. Awalnya film animasi ini bertujuan untuk mendidik anakanak agar lebih mengerti tentang seputarkeagamaan. Kini film animasi Syamil dan Dodo hadir di TV Swasta ${ }^{4}$.

Berdasarkan masalah-masalah di atas, penulis tertarik untuk meneliti tentang pesanpesan dakwah dalam film animasi Syamil dan Dodo, dengan judul DAKWAH

\footnotetext{
3https://youtu.be/6WsDSkdqvOE (diundu pada tanggal 12 januari 2018, pukul 00.49 WIB)

4http://emangmantep.com/serial-animasi-asli-indonesiapernah-dan-sedang-tayang-televisi/diakses pada 25/09/2017 pukul 15.17
} 
MELALUI FILM ANIMASI (Analisis pesan dakwah pada film animasi Syamil dan Dodo dengan judul "Sabar").

\section{KAJIAN TEORI}

1. Komunikasi Massa

Menurut Bittner. komunikasi massa adalah pesan yang dikomunikasikan melalui media massa pada sejumblah besar orang. Dari definisi tersebut dapat diketahui bahwa komunikasi massa itu menggunakan media massa (Ardianto, 2012:3).

2. Karakteristik

a) Komunikator terlembaga

Ciri komunikasi massa yang pertama adalah komunikatornya. Kita sudah memahami bahwa komunikasi massa itu menggunakan media massa, baik media cetak maupun elektronik, dengan mengingat kembali pendapat Wright, bahwa komunikasi itu melibatkan lembaga, dan komunikatornya bergerak dalam organisasi yang kompleks.

b) Pesan bersifat umum

Komunikasi massa itu bersifat terbuka, artinya komunikasi massa itu ditunjukan untuk semua orang dan tidak ditunjukan untuk sekelompok orang tertentu. Oleh karenanya komunikasi massa bersifat umum. Pesan komunikasi massa dapat berupa fakta, peristi ataupun opini. Namun tidak semua fakta dan peristiwa yang terjadi di sekeliling kita dapat dimuat dalam media massa. Pesan komunikasi massa yang dikemas dalam bentuk apapun harus memenuhi kriteria penting ataupun menarik, atau penting sekaligus menarik, bagi sebagian besar komunikan.

c) Komunikannya anonim dan heterogen

Komunikan pada komunikasi massa bersifat anonim dan heterogen. Pada komunikasi antarpersonal, komunikator akan mengenal komunikannya, mengetahui identitasnya, seperti: nama, pendidikan, pekerjaan, tempat tinggal, bahkan mungkin mengenal sifat dan perilakunya. Sedangkan komunikasi massa, komunikator tidak mengenal komunikan (anonim), karena komunikasinya menggunakan media dan tidak tatap muka.

d) Media massa menimbulkan keserampakan

Kelebihan komunikasi massa dibandingkan dengan komunikasi lainnya, adalah jumlah sasaran khalayak atau komunikan yang dicapainya relatif banyak dan tidak terbatas. Bahkan lebih dari itu, komunikan yang banyak tersebut secara serempak pada waktu yang bersamaan memproleh pesan yang sama pula. Menurut Effendy (1981) mengartikan keserempakan media massa itu sebagai keserempakan kontak dengan sejumlah besar penduduk dalam jarak yang jauh dari komunikator, dan penduduk tersebut satu sama lainnya berada dalam keadaan terpisah.

e) Komunikasi mengutamakan isi ketimbang hubungan 
Salah satu prinsip komunikasi adalah bahwa komunikasi mempunyai dimensi isi dan dimensi hubungan. Dimensi isi menunjukan muatan atau isi komunikasi, yaitu apa yang dikatakan, sedangkan dimensi hubungan menunjukan bagaimana cara mengatakannya, yang juga mengisyaratkan bagaimana hubungan para peserta komunikasi itu. Sementara Rakhmat menyebutnya sebagai proporsi unsur isi dan unsur hubungan.

f) Komukasi massa bersifat satu arah

Selain ada ciri yang merupakan keunggulan komunikasi massa dibandingkan dengan komunikasi lainnya, ada juga ciri komunikasi massa yang merupakan kelemahannya. Karena komunikasinya melalui media massa, maka komunikator dan komunikannya tidak dapat melakukan dialog sebagaimana halnya terjadi dalam komunikasi antar persona. Dengan kata lain, komunikasi massa itu bersifat satu arah.

g) Stimulasi alat indra terbatas

Ciri komunikasi massa lainnya yang dianggap salah satu kelemahannya, adalah stimulasi alat indra yang terbatas. Pada komunikasi antarpersona yang bersifat tatap muka, maka seluruh alat indra pelaku komunikasi, komunikator dan komunikan, dapat digunakan secara maksimal.

h) Umpan balik tertunda (Deleyed) dan tidak langsung (Indirect)

Komponen umpan balik atau yang lebih populer dengan sebutan feedback merupakan faktor paling penting dalam proses komunikasi antarpesona, komunikasi kelompok, dan komunikasi massa. Efektivitas komunikasi seringkali dapat dilihat dari feedblack yang disampaikan oleh komunikan.

\section{Film}

Undang-undang Nomer 33 Tahun 2009 tentang perfilman pada Bab 1 Pasal 1 menyebutkan, yang dimaksud dengan film adalah karya seni budaya yang merupakan pranata sosial dan media sosial dan media komunikasi massa yang dibuat berdasarkan kaidah sinematografi dengan atau tanpa suara dan dapat dipertunjukan.Film merupakan salah satu media komunikasi massa. Dikatakan sebagai media komunikasi massa karena merupakan bentuk komunikasi yang menggunakan saluran (media) dalam menghubungkan komunikator dan komunikan secara massal, dalam arti berjumblah banyak, tersebar dimana-mana, khalayaknya heterogen dan aninom, dan menimpulkan efek tertentu (Vera, 2014:91).

\section{a. Fungsi film}

Tujuan khalayak menonton film terutama yaitu ingin memperoleh hiburan.akan tetapi dalam film dapat terkandung fungsi informatif maupun edukatif, bahkan persuasif.Hal ini pun sejalan dengan misi hiburan dan media edukasi digunakan untuk pembinaan generasi muda (Ardianto, 2012:145).

1) Kartun dan Film Kartun 
Kartun meupakan cikal bakal tebentuknya film kartun.Kartun yang merupakan sebuah goresan yang menggunakan tangan, secara hakiki tidak dapat dilepas dari induknya, yakni seni rupa. Sejak dahulu, seni yang satu ini terkenal diolah oleh tangan-tangan orang terampil, seperti Honer Dumier, Francisco da Goya, Leonardo Da Vinci, dan masih banyak lagi. Namun, yang dianugrahi gelar sebagai pelopor kartun adalah Honore Dumier.Kartun yang didefinisikan sebagai gambaran yang bersifat humoritis, kadang hanya bersifat lucu dan menarik, kadang dengan tujuan mencela atau mencemooh keadaan social atau seseorang. Namun lebih ditekankan lagi, bahwa katun lebih meupakan pencerminan ciri-ciri kemanusiaan pada umumnya secara karikatural ( Vera, 2014: 96).

2) Dakwah

Dakwah adalah mengajak atau menyeru untuk melakukan kebajikan danmencegah kemungkaran, mengubah umat dari satu situasi kepada situasi lain yang lebih baik dalam segala bidang, merealisasi ajaran islam dalam kehidupan sehari-hari bagi seorang pribadi, keluarga, kelompok atau massa, serta bagi kehidupan masyarakat sebagai keseluruhan tata hidup bersama dalam rangka pembangunan bangsa dan umat manusia (Aziz, 2012:13).
3) Film sebagai media dakwah

Film sebagai penyampaian pesanpesan Islam tidak lagi dengan kata-kata bahwa berkerudung itu wajib, menutup aurat itu kemestian seorang muslim. karena katakata tersebut tidak sesuai dengan perkembangan budaya masyarakat (Aripudin, 2013:38). Dalam arti Film sendiri yaitu bukan hanya memperoleh hiburan saja akan tetapi film dapat terkandung fungsi informatif maupun edukatif, bahkan persuasif. Hal ini pun sejalan dengan misi hiburan dan media edukasi digunakan untuk pembinaan generasi muda (Ardianto, 2012:145)

\section{4) Pesan dakwah}

Pesan dakwah tidak hanya berupa sumber utama, yaitu ayat Al-Quran dan hadis saja, tetapi juga beberapa uraian dari sumbersumber lainnya sebagai berikut (Aziz, 2012:318-330):

Ayat-ayat Al-Quran adalah wahyu penyempurna. Seluruh wahyu yang diturunkan Allah SWT. Kepada nabi-nabi terdahulu termaktub dan teringkas dalam AlQuran. Dengan mempelajarinya seseorang dapat mengetahui kandungan Kitab Taurat, Kitab Zabur, Kitab Injil.

Hadis Nabi SAW yaitu segala hal yang berkenan dengan Nabi SAW. Yang meliputi ucapan, perbuatan, ketetapan, sifat bahkan cirri fisiknya dinamakaan hadis.

5) Semiotika Roland Barthes 
Semiotika adalaah studi mengenai tanda (signs) dan simbol yang merupakan tradisi penting dalam pemikiran tradisi komunikasi. Tradisi semiotika mencangkup teori utama mengenai bagaiman tanda mewakili objek, ide, situasi, keadaan, perasaan, dan sebagainya yang berada diluar diri (Morissan, 2013: 27).

\section{METODOLOGI PENELITIAN}

1. Jenis penelitian

Jenis penelitian ini termasuk jenis penelitian kualitatif. Ciri khas penelitian kualitatif ini terletak pada tujuannya menurut Bogdan dan Taylor mendefinisikan yang dikutip pada buku "metodelogi kualitatif" yang sebagai prosedur penelitian yang menghasilkan data deskriptif berupa katakata tertulis atau lisan dari orang-orang dan perilaku yang diamati (Moleong, 2004:3).

2. Pendekatan yang digunakan

Pendekatan yang digunakan dalam penelitian ini ialah semiotika model dari Roland Barthes, Semiotik adalah metode analisis untuk mengkaji data (Sobur, 2013:15). Semiotik yaitu sebagai suatu model memahami dunia sebagai sistem hubungan yang memiliki unit dasar yang disebut dengan 'tanda'(Bugin, 2012:170). Dan ilmu ini menganggap bahwa fenomena sosial atau masyarakat dan kebudayaan itu merupakan tanda-tanda, sistem-sistem, aturan-aturan, konveksi-konveksi yang memungkinkan tanda-tanda tersebut mempunyai arti (Bugin, 2012:173).

\section{Sumber Data}

Data jenis dan sumber data penelitian ini menggunakan dua macam jenis dan sumber data yaitu:

a. Data primer

Data primer ialah data yang berasal dari sumber asli yang harus mencari narasumber dari objek penelitian untuk kita jadikan sebagai sarana mendapatkan informasi ataupun data (Sarwono, 2006:13).Dalam penelitian ini yang menjadi sumber data primer adalah tayangan film animasi Syamil dan Dodo sebagai objek penelitian.

\section{b. Data Sekunder}

Data sekunder merupakan data yang sudah tersedia sehingga kita tinggal mencari dan mengumpulkan (Sarwono, 2006:11). Data skunder dalam penelitian ini diantaranya ; buku, artikel, dan internet yang berkaitan dengan penelitian ini.

\section{Teknik Pengumpulan Data}

a. Observasi

Observasi adalah dengan cara mengumpulkan datadengan pengamatan dan pencatatan terhadap fenomena yang diamatioleh mata dan apa yang didengarkan oleh kedua telinga peneliti. Pengamatan atau observasi dilakukan dengan melihat dan mengamati sendiri, kemudian mencatat perilaku dan kejadian sebagaimana yang terjadi pada keadaan sebenarnya (Moleong, 2004:174).

b. Dokumentasi 
Dokumentasi adalah teknik pengumpulan data dengan cara mengumpulkan setiap bahan tertulis ataupun film (Meleong, 2004:216).

Maka dalam penelitian ini penulis mengumpulkan data yang berbentuk kajian dokumen tertulis berupa catatan, buku, transkip, arsip, dan video.

Data-data yang dimaksud peneliti adalah yang berkaitan dengan film animasi Syamil dan Dodo.

\section{Teknik Analisis Data}

Teknis analisis data penelitian ini, menggunakan analisis semiotik model dari Roland Barthes tentang simbol. Arti dari simbol sendiri adalah tanda yang menunjukan hubungan alamiah antara penanda dengan petandanya (Sobur, 2013:42).

Roland Barthes mengungkapkan bahwa bahasa merupakan sebuah sistem tanda yang mencerminkan asumsi-asumsi dari masyarakat tertentu dalam waktu tertentu. Barthes menggunakan teori signifiant-signifie yang dikembangkan menjadi teori tentang metabahasa dan konotasi.Istilah significant menjadi ekspresi (E) dan signifie menjadi isi (C).namun Barthes, mengatakan bahwa antara $\mathrm{E}$ dan $\mathrm{C}$ harus ada relasi (R) tertentu, sehingga membentuk tanda (sign, Sn).

\section{HASIL DAN PEMBAHASAN}

Analisis semiotika pesan dakwah yang terkandung dalam film animasi Syamil dan Dodo tersaji berikut ini.
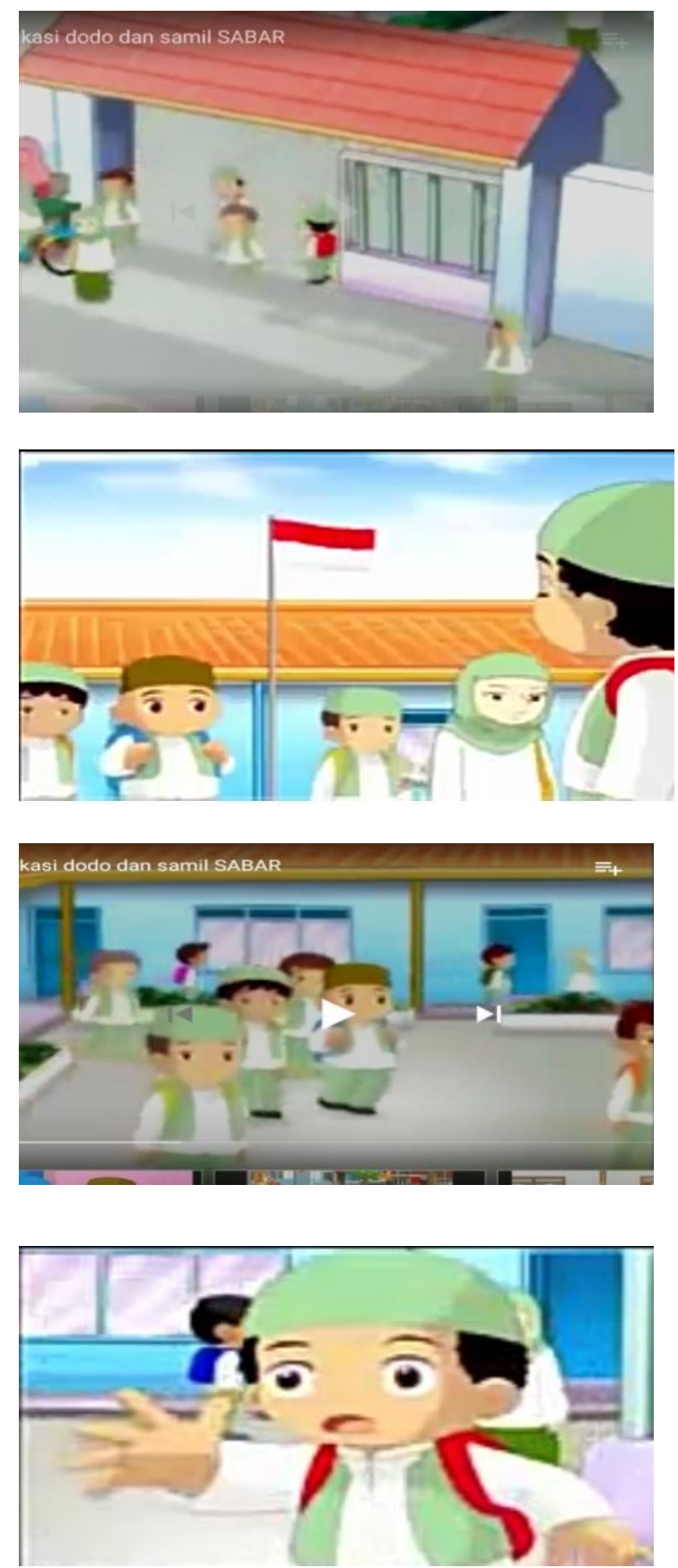

Gambar 1 Adegan 1-4 dalam Film Syamli dan Dodo

Verbal ;

"Kemana ya Dodo dan Anton,apa mereka dimarahi oleh bu guru" 
( Syamil berdiri di depan gerbang sekolah, sedang mencari Dodo dan Anto untuk pulang bersama. Tidak berapa lama, kemudian datang Dodo dan Anto. Anto menyambut Syamil dengan wajah yang jemberut atau kusut sedangkann Dodo dengan muka senang).

Non Verbal ;

Syamil menunggu Dodo dan Anto di depan gerbang sekolah yang tak kunjung datang, yang membuat Syamil Khawatir dan skspresi wajahnya yang gelisah.

Secara denotasi, di saat waktu pulang sekolah Syamil menunggu Dodo dan Anto untuk pulang bersama. Akan tetapi Dodo dan Anto belum terlihat sehingga membuat Syamil Khawatir. Tidak berapa lama mereka datang dengan spresi wajah yang berbeda, Dodo dengan wajah yang tenang sedangkan Anto dengan wajah yang kusut.

Secara konotasi, Rasa peduli terhadap teman sudah diajarkan semenjak dini kala.setiap siswa diajarkan untuk mempunyai rasa pedulu dan perhatian kepada sesama teman. Dalam hal ini Syamil menunjukan rasa khawatrinya sebagai bentuk kepedulian tehadap Dodo dan Anto,yang mana sesuai dengan yang diajarkan di sekolah.

Secara mitos, Mayoritas di Indonesia, biasanya seseorang yang menunjukan wajah kusut,atau asem, berarti dia mempunyai masalah atau sedang tertimpa hal buruk.

\section{Pesan-pesan Dakwah dalam Film Animasi Syamil dan Dodo dengan Ajaan Islam}

\section{a. Akhlak}

Dalam adegan scene 1 dan 2 Ketika Syamil menggu di depan gerbang sekolah menunggu Dodo dan Anto yang tak kunjung datang, rasa khawatiran yang ada pada Syamil, adapun paparan arti seorang teman sebagai berikut:

\section{- Teman}

Teman, kawan, atau sahabat adalah orang yang bersama-sama bekerja (berbuat, berjalan), menjadi pelengkap (pasangan). Manusia adalah makhluk sosial. Tidak bias hidup sendiri. Kita butuh teman untuk menjalani dan memenuhi ragam kebutuhan hidup. Bahkan, teman adalah pe. Persahabatan

- Persahabatan

Memungkinkan seseorang untuk berhubungan secara intim, Penuh arti dan relative kekal tanpa memperhatikan status dan aturan-aturan. (dalam Ahmadi, 1991) mengemukakan bahwa persahabatan adalah hubungan pribadi yang akrab atau intim yang melibatkan setiap individu sebagai suatu kesatuan; sedangkan hubungan pertemanan merupakan hasil dari suatu hubungan formal dan suatu tingkat permulaan dalam perkembangan kearah persahabatan. Menurut Parker dan Asher (1993) terdapat enama spekkualitas persahabatan, yaitu ${ }^{5}$ :

5http://eprints.ums.ac.id/46896/21/02.\%20Naskah $\%$ 20Publikasi.pdf (diundu pada tanggal 04 Juni 2018. Pukul 20.33 WIB). 
a. Dukungan dan kepedulian adalah sejauh mana hubungan ditandai dengan kepedulian, dukungan dan minat.

b. Pertemanan dan rekreasi adalah sejauh mana menghabiskan waktu bersama dengan teman-teman baik di dalam maupun di luar lingkungan akademik atau kerja.

c. Bantuan dan bimbingan adalah sejauh mana teman-teman berusaha membantu satu sama lain dalam menghadapi tugastugas rutin dan menantang.

d. Pertukaran yang akrab adalah sejauh mana hubungan ditandai dengan pengungkapan informasi pribadi dan perasaan.

e. Konflik dan penghianatan adalah sejauh mana hubungan ditandai dengan argumen, perselisihan, rasa kesal, dan ketidak percayaan.

f. Pemecahan masalah adalah sejauh mana perselisihan dalam hubungan diselesaikan secara efisien dan baik. Dari persahabatan sebagai berikut:

1) Sukarela.

Dalam persahabatan, hubungan dibentuk atas dasar kesuka relaan penuh, sedangkan dalam berteman masih terdapat kesan kita berteman selama masih ada kerja sama.

2) Unik.
Keunikan merupakan ciri khas persahabatan yang menjadikannya tidak dapat digantikan oleh bentuk hubungan lain.

3) Hormat kepada Teman dan Sahabat

Sikap hormat kepada teman sahabat merupakan sikap terpuji dalam akhlak Islam.Karena teman dan sahabat adalah orang yang kita ajak bergaul dalam kehidupan, berbuat baik terhadap teman dan sahabat sangat dianjurkan oleh Rasulullah kepada para sahabatnya.Bahkan para sahabat Rasulullah yang berasal dari Mekah (sahabat Muhajirin), dipersaudarakan oleh Rasulullah yang berasal dari Madinah (sahabat Anshar).Ikatan persaudaraan ini adalah bentuk saling menghormati di antara teman dan sahabat, yang di ajarkan oleh Allah (Amin Samsul, 2016: 223).

4) Berbuat Baik (Ihsan)

Berbuat baik adalah perbuatan terpuji, berbuat ihsan juga akan dapat menciptakan suasana haermonis dalam hubungan dengan masyarakat. Manusia diciptakan dalam kondisi saling ketergantungan antara yang satu dengan yang lain. Interaksi antara manusia tidak akan berjalan efektif jika tidak ada rasa saling menghargai antar sesama. Alquran dan sunnah telah menuntun kita bagaimana seharusnya bersikap saling menghargai (Amin Samsul, 2016: 2010).

\section{- Macam-macam Sabar}

Menurut Sayyid Abdullah terbagi menjadi 4 bagian yaitu: (Abdullah Sayid, 1997: 248-251). 
1) Sabar dalam melaksanakan ketaatan yaitu secara batiniyah dengan berpegang pada keikhlasan dan kehadiran hati di dalamnya; dan secara lahiriyah dengan terus-menerus mengerjakannya dengan rajin dan bersemangat serta sesuai dengan cara-cara yang disyaratkan.

2) Sabar menghadapi maksiat

Ini akan terwujud, secara lahiriyah dengan menghindarinya serta menjahu dari tempat yang menjurus ke arahnya. Dan secara batiniyah dengan mencegah hati dari perkataan tentangnya ataupun cenderung kepadanya.

3) Sabar dalam mengingat-ingat perbuatanperbuatan dosa di masa lalu

Ini hanya dapat dibenakan jika dapat mengakibatkan timbulnya rasa cemas dan penyesalan atau, jika tidak, maka sebaiknya jangan dilakukan.Di antara yang dapat menerbitkan kesabaran seperti ini ialah mengingat hukuman yang segera ataupun dimasa mendatang yang di ancamkan oleh Allah atas pelaku maksiat.

4) Sabar menghadapi kesulitan

Sabar jenis ini terbagi menjadi dua jenis yaitu :

a. Kesulitan yang datang dari Allah secara langsung; seperti penyakit, kemiskinan kehilangan harta benda serta kematian sanak kerabat atau teman yang dikasihi, sabar dalam hal ini, secara batiniyah dengan menghindari kesedihan dan penyesalan berlebihan, dan secara lahiriyah dengan tidak mengeluhkan kepada manusia mana pun juga.

b. Kesulitan-kesulitan lainnya yaitu yang disebabkan oleh manusia lain berupa gangguan pada diri, kehormatan dan harta benda seseorang. Kesempurnaan bersabar atas hal-hal seperti ini dapat terewujud dengan mencegah diri dengan mengharapkan pertolongan Allah atau pun didorong oleh pemaaf karena mengharapkan pahala dari-Nya SWT.

5) Jujur (Shidqu)

Berlaku benar dan jujur ini merupakan dorongan suara hati manusia, yang berjalan dengan tuntutan ilmu penngetahuan dan perintah agama. Menurut Al-Ghazali, jujur yang sempurna menghilangkan sifat riya' dalam diri (Amin Samsul, 2016: 205).

\section{b. Akidah}

Dalam adegan scene 3 sampai 5 Ketika Dodo dapat nilai kecil ulangan di sekolahnya tetapi Dodo sabar menerimanya, tapi harus lebih bersemangat lagi untuk belajar, dan ketika Dodo, Syamil, dan Anto lapar, tetapi makanan yang di masak oleh Ibu nya Dodo belum matang, harus bersabar menunggu makanan yang dimasak oleh Ibu nya Dodo, adapun paparan arti sabar sebagai berikut:

1) Sabar

Sabar menurut terminologi adalah keadaan jiwa yang kokoh, stabil, dan konsekuen dalam pendirian. Jiwanya tidak tergoyahkan, pendiriannya tidak berubah 
bagaimanapun berat tantangan yang dihadapi. Sedangkan menurut Athaillah, sabar adalah tabah menghadapi cobaan, tanpa menampakkan keluhan sedikit pun.Sikap sabar dilandasi oleh anggapan bahwa segala sesuatu yang terjadi merupakan iradah Tuhan (Amin Samsul, 2016: 198).

a. 2) Macam-macam Sabar

Menurut Sayyid Abdullah terbagi menjadi 4 bagian yaitu: (Abdullah Sayid, 1997: 248-251).

- Sabar dalam melaksanakan ketaatan

yaitu secara batiniyah dengan berpegang pada keikhlasan dan kehadiran hati di dalamnya; dan secara lahiriyah dengan terus-menerus mengerjakannya dengan rajin dan bersemangat serta sesuai dengan cara-cara yang disyaratkan.

- Sabar menghadapi maksiat

Ini akan terwujud, secara lahiriyah dengan menghindarinya serta menjahu dari tempat yang menjurus ke arahnya. Dan secara batiniyah dengan mencegah hati dari perkataan tentangnya ataupun cenderung kepadanya.

- Sabar dalam mengingat-ingat perbuatanperbuatan dosa di masa lalu

Ini hanya dapat dibenakan jika dapat mengakibatkan timbulnya rasa cemas dan penyesalan atau, jika tidak, maka sebaiknya jangan dilakukan.Di antara yang dapat menerbitkan kesabaran seperti ini ialah mengingat hukuman yang segera ataupun dimasa mendatang yang di ancamkan oleh Allah atas pelaku maksiat.

- Sabar menghadapi kesulitan

Yang terbagi menjadi dua jenis yaitu :

Yang datang dari Allah secara langsung; seperti penyakit, kemiskinan kehilangan harta benda serta kematian sanak kerabat atau teman yang

a) dikasihi, sabar dalam hal ini, secara batiniyah dengan menghindari kesedihan dan penyesalan berlebihan, dan secara lahiriyah dengan tidak mengeluhkan kepada manusia mana pun juga.

b) Kesulitan-kesulitan lainnya yaitu yang disebabkan oleh manusia lain berupa gangguan pada diri, kehormatan dan harta benda seseorang. Kesempurnaan bersabar atas hal-hal seperti ini dapat terewujud dengan mencegah diri dengan mengharapkan pertolongan Allah atau pun didorong oleh pemaaf karena mengharapkan pahala dariNya SWT.

\section{c. Jujur (Shidqu)}

Shidqu secara etimologi berarti jujur,benar. Adapun yang dimaksud jujur, adalah memberitahukan, menuturkan sesuatu dengan sebenarnya, sesuai dengan fakta (kejadian)nya, pemberitahuan ini tidak hanya dalam ucapan, tetapi juga dalam perbuatan. Berlaku benar dan jujur ini merupakan dorongan suara hati manusia, yang berjalan dengan tuntutan ilmu penngetahuan dan perintah agama. Menurut Al-Ghazali, jujur 
yang sempurna menghilangkan sifat riya' dalam diri (Amin Samsul, 2016: 205).

1. Jenis-jenis perilaku jujur

Jenis-jenis kejujuran sebagaimana dipaparkan oleh M. Amin Syukur dalam bukunya Hati ke Hati, menjelaskan tentang beberapa jenis kejujuran sebagai berikut ${ }^{6}$ :

2. Jujur dalam hati yaitu menghiasi hate dengan iman kepada Allah, sehingga akan bersih dari hati yang kotor. Hati yang jujur akan tercermin dalam niat yang tulus dan ikhlas.

3. Jujur dalam Perkataan berarti bahwa segala yang disampaikan, pertanyaan yang diajukan, dan jawaban yang diberikan, semata-mata adalah kebenaran. Orang yang jujur dalam perkataan akan dipercaya oleh siapa saja.

4. Jujur dalam perbuatan dan pergaulan yaitu segala prilaku yang sesuai dengan syariat islam. Orang yang memiliki sifat ini, tidak menipu, tidak memalsu dan tidak berkhianat, serta dalam berbuat baik tidak pernah mengharap balasan, kecuali dari Allah.

5. Jujur dalam kemauan yaitu Orang yang memiliki sifat jujur dalam kemauan, sebelum melakukan tindakan akan dilakukan terlebih dahulu penilaian dan pertimbangan,

6http://repository.iainpekalongan.ac.id/1223/9/1 2.BAB\%20II.pdf(diundu pada tanggal $04 \mathrm{Juni}$ 2018. Pukul 20.00 WIB). kemudian diputuskan dan diniatkan untuk melakukan perbuatan tersebut.

6. Jujur dalam kenyataan hidup yaitu bersikap apaadanya, dalam berbuat dan berkata kapanpun dand imanapun, tidak menambahnambah atau mengurangi karunia Allah yang diberikan kepadanya.

\section{c. Syariah}

Dalam adegan scene 6 sampai 8 Di ruang makan Syamil, Dodo, Anto dan Nadiyah sambil menunggu makanan yang belum matang, Nadiyah menjelaskan kepada Syamil, Dodo, dan Anto tentang bersabar dalam beribadah seperti Sholat dan Puasa. Karena Sholat dan Puasa meupakan Syariah Islam yang mana diperintahkan oleh Allah dan Rosulnya.

\section{PENUTUP}

Setelah menguraikan dan menganalisis pesan-pesan dakwah yang terdapat dalam film animasi Syamil dan Dodo pada episode yang bertema Sabar. Maka dapat di simpulkan.

Pesan-pesan dakwah dalam film animasi Syamil dan Dodo adalah kesabaran, saling menghormati terhadap satu sama lain, Berbicara kepada yang lebih tua harus sopan santun, ramah dan Kejujuran. Terlihat pesan tersebut yang berjudul sabar, walaupun Dodo sangat lapar tetapi Dodo sabar untuk menunggu makanan yang di masak oleh Ibunya, kemudian ketika ka Nadiyah masuk rumah selalu mengucapkan salam telebih dahulu. 
Film animasi Syamil dan Dodo pada episode yang berjudul Sabar ini terhadap beberapa proses pembelajaran bagi anakanak dapat di jadikan referensi orang tua maupun pendidikan untuk menambah nilainilai pendidikan untuk lebih respct terhadap satu sama lain, supaya lebih lembut berbicara kepada yang lebih tua dengan sopan santun, supaya lebih bersabar, dan jujur.

Pesan dakwah pada film animasi Syamil dan Dodo ini, Pesan dakwah dalam penelitian Film Syamil dan Dodo yaitu mengajarkan kesabaran dengan cara kemasan anak-anak, supaya anak-anak mengerti dan tidak keliru memahami arti sabar.

\section{DAFTAR PUSTAKA}

Ardianto, Ervinaro. 2012. Komunikasi Massa. Bandung: Simbosa Rekatama Media.

Aziz, Moh Ali. 2012. Ilmu Dakwah. Jakarta: Kencana.

Al-Quran. 2013. Ali Imron. Ayat 3.Bandung:Mikraj Khazanah Ilmu.

Aripudin, Acep. 2013. Sosiologi Dakwah. Bandung: Kencana.

Amin, Samsul. 2016, IlmuAkhlak. Jakarta: Amzah

Bugin, Burhan. 2007.

PenelitianKualitatif. Jakarta: Kencana.

Meleong, Lexy. 1996.

MetodologiPenelitianKualitatif.

Bandung: RemajaRosdakarya

Sobur, Alex. 2013.SemiotikaKomunikasi.

Bandung: RemajaRosdakarya

Sobur, Alex. 2004. AnalisisTeks Media.

Bandung: RemajaRosdakarya
Vera, Nawiroh. 2014.

SemiotikadalamRisetKomunikasi.

Bogor: Ghalia Indonesia.

Sarwono, Jonathan. 2006. Analisis Data

MenggunakanSPSS. Yogyakarta:

C.V Andi Offset.

Morissan, 2013.Teorikomunikasi. Bogor:

Ghalia Indonesia.

Aretha Kurnia. 2009. Persepsi Ibu Rumah

Tangga Kelurahan Tomang pada

Tayangan Sinetron Inayah di

Indosiar.http://digilib.mercubuana.a

c.id .pdf. (diunduh pada tanggal 18

desember 2017, pukul 15.33 WIB)

RamadhianFadillah, Peristiwa Film

KartunSyamildan Dodo

masukNominasiKpi Award 2014.

https://www.merdeka.com.

(diunduhpadatanggal 22 desember

2017, pukul 14.30 WIB)

Youtub Film

SyamildanDodo.Sabar.https://youtu.

be/6WsDSkdqvOE

(diunduhpadatanggal 12 januari

2018, pukul 00.49WIB)

EmangMantap. Com. Serial AnimasiAsli

Indonesia Pernahdansedang di

TayangTelevisi.http://emangmantep

.com. (diaksespada 25/09/2017

pukul 15.17).

Risalah Islam. Ciri-

CiriTemanSejatimenurutIslam.http:/ /www.risalahislam.com.

(diunduhpadatanggal 04 Juni 2018. Pukul 20.28 WIB).

AnikaPutri.HubunganAntaraPersahabata ndengan

Esteem.http://eprints.ums.ac.id.pdf (diunduhpadatanggal 04Juni 2018. Pukul 20.33 WIB). Abrasyi, M. Athiyyah , 2003: Prinsip-prinsip Dasar Pendidikan, Bandung: Pustaka Setia

Rosdakarya. 